\title{
Media reform since 1987
}

Taiwan's media are still at an early stage of democratisation but it cannot be denied that progress has been made

\section{Gary D. Rawnsley and Ming-Yeh T. Rawnsley}

\section{(2) OpenEdition}

\section{Journals}

Electronic version

URL: http://journals.openedition.org/chinaperspectives/440

DOI: $10.4000 /$ chinaperspectives. 440

ISSN: 1996-4617

\section{Publisher}

Centre d'étude français sur la Chine contemporaine

\section{Printed version}

Date of publication: 1 December 2004

ISSN: 2070-3449

Electronic reference

Gary D. Rawnsley and Ming-Yeh T. Rawnsley, « Media reform since 1987 », China Perspectives [Online], 56 | november - december 2004, Online since 29 December 2008, connection on 28 October 2019.

URL : http://journals.openedition.org/chinaperspectives/440; DOI : 10.4000/chinaperspectives.440

This text was automatically generated on 28 October 2019

(c) All rights reserved 


\section{Media reform since 1987}

Taiwan's media are still at an early stage of democratisation but it cannot be denied that progress has been made

\section{Gary D. Rawnsley and Ming-Yeh T. Rawnsley}

1 In his inauguration speech of May 20th 2004, President Chen Shui-bian discussed his vision for his second administration, and commentators on Taiwan politics have dissected and analysed the meaning and implications of his plans. One sentence, buried within a paragraph on reform, has largely gone unnoticed: "Persist with reform - We shall forge ahead in response to the people's demand for reform in our political and judicial system, in the educational system, and in our financial and fiscal infrastructures; for improvement in the quality of our media ${ }^{1}$; and, for comprehensive social reform".

2 It is only too easy to miss this reference to the media as Chen's discussion of the constitutional "re-engineering project" dominated his inaugural address. The glass is either half empty or half full: critics may claim that Chen glossed over media reform because his administration believe it is a non-issue; the more optimistic among us might take heart from the fact that media reform was mentioned at all, and the brief reference to it is an indication that much has already been achieved.

Both sides of this debate agree that media reform is a valuable indicator of democratisation. It provides a benchmark that reveals an abundance of information about the levels of freedom, tolerance, social justice and pluralism within a political system $^{2}$. We now accept that the media were central to the development of both democratic culture and procedures in Taiwan ${ }^{3}$. The media landscape has extended beyond any previously imagined horizon, and audiences can choose from a plethora of outlets-print, broadcast and internet-demonstrating that Taiwan has created a genuinely pluralistic media environment.

4 This article reviews the changes that have taken place since the lifting of martial law (jieyanfa) in 1987 and gives a perspective of how the media are faring at the beginning of Chen Shui-bian's second term. His administration is routinely criticised for not having paid sufficient attention to irregularities that continue to impede the development of a free and democratic media. Detractors were particularly vocal during 
and after the controversial 2004 presidential election when the predominantly "blue" media were able to present a decidedly prejudiced picture of the campaign, raising again the problem of biased coverage of politics ${ }^{5}$.

However, while the record reveals that Taiwan's media are still at an early stage of democratisation we cannot deny the progress made, and that Taiwan's media look increasingly similar to those operating in systems at comparatively similar stages of democratic consolidation ${ }^{6}$.

Under the KMT

When the Kuomintang (Nationalist Party) began the dual processes of social liberalisation and political democratisation in 1987, the state system had already been exercising tight control over print and broadcast media for thirty years. The government had enacted a series of laws-some vague, some more explicit-that detailed the responsibilities of the media and the sanctions they faced if the laws were violated. Directive No. 3148, issued in June 1951, was the most interesting as it suggested the more insidious methods that the government would continue to use to control the media. (The Directive used the need for paper rationing to justify why the press were subject to politically managed restraint ${ }^{7}$ ). Many such laws were as vague and arbitrary as possible, thus allowing the state to exercise expediency in their interpretation and application. In contrast, the government felt no need to hide behind paper rationing in the martial law, Article 11 of which defended limits to press freedom on grounds of national security, while the Law on Publications (chubanfa) ${ }^{8}$ described how the government could close a daily newspaper without recourse to judicial process or authority ${ }^{9}$. Moreover, while government censors did not inspect newspaper copy before publication, the legal machinery did allow the government to recall and confiscate newspapers after publication if they had printed anything that conflicted with political or military interests.

7 However, the most direct method of influence was also the most simple: ownership of media enterprises. In addition to claiming legal authority, in the early 1980s the KMT owned four national daily newspapers, the government owned two, and the military five, but the implied separation was deceptive because of the overlapping character of party/state/military political authority. A similar structure managed the three oldest national television stations, Taiwan Television Company (TTV), China Television Company (CTV) and Chinese Television System (CTS). Again, these were owned by the government, the party and the military (See Table 1).

In addition, the KMT government successfully managed the media through the creation of a complex patron-client network that allowed agencies representing the KMT, the provincial government and the state to manage media appointments. This meant that newspaper editors either were members of the KMT or were supportive of the KMT's political agenda, thus sympathetic journalists, owners and political appointees were located in prominent and powerful "gate-keeping" positions within the media. For example, the proprietors of the two privately owned newspapers with the highest circulation, Zhongguo shibao (China Times) and Lianhe bao (United Daily News) were members of the KMT Central Standing Committee. These private newspapers may have challenged the government press for readership, but their owners guaranteed that they would be supportive of the government. "To a certain extent, the obligation to be profitable, the need to sell, incited the private papers to distance themselves from 
propaganda, while remaining within limits acceptable to the regime, in order not to end up being closed down"10.

Exceptions to this pattern of ownership were rare, but did offer some hope that the voice of the Taiwanese would find a channel of expression in mainstream publications. Zili wanbao (Independent Evening News) and Minzhong ribao (People's Daily) were owned and controlled by Taiwanese. Taiwan shibao (Taiwan Times), located in Kaohsiung, was also privately owned and independent, publishing what Bruce Jacobs called "strongly worded editorials and comments" ${ }^{11}$. Even in a media environment subject to myriad political and legal restrictions, the KMT was prepared to accept a level of press independence.

10 Such limited exceptions notwithstanding, the restricted political environment of Taiwan under martial law constrained the media from doing little other than comply with a government demand that they act as agencies of transmission for the official ideology. Attempts to evade the law were met with severe punishment: during the "White Terror" (baise kongbu) between 1950 and 1987, hundreds of reporters, writers and editors were purportedly harassed, interrogated and often jailed ${ }^{12}$.

After martial law

11 The lifting of martial law in 1987, and the social liberalisation and political democratisation that followed, allowed for the dramatic transformation of Taiwan's media environment. The most noticeable change was the rapid proliferation of legal media. The figures are instructive. By mid-2003, there were:

- 602 newspapers (31 between 1951 and 1987; 393 in August 1999)

- 174 radio stations (prior to 1993, there were only 33; call-in radio stations were legalised in 1994)

- Four national television stations (compared to three when liberalisation began in 1987)

- Access to hundreds of cable channels broadcasting local and international programmes (the transmission and reception of cable television broadcasts remained illegal until 1993) ${ }^{13}$. These channels include a national public television system.

The KMT's role in this process should be acknowledged, and Taiwan passed a milestone in September 1989 when the then Director of the Government Information Office (GIO, xinwenju $)^{14}$, Shaw Yu-ming, observed that self-regulation by the media was preferable to state supervision. He also recognised that, in a democratic political system, the media have a responsibility to scrutinise the decisions and behaviour of the government and hold it accountable for its actions: "The government," he said, "is ... under the surveillance of the media, and it is not suitable for the government to use administrative means or the law to punish them. That would raise criticisms about freedom of the press being hampered"15. Chu Jiying, Director of the KMT Cultural Affairs Department echoed these sentiments. In a democracy, he said: "the press is the spokesman of the public's interests. I believe that the role of the party's spokesman is to provide information, not to control the news. He must manage information, not control it. He must explain the party's policy to the media and relay public opinion to his superiors. The rigid, domineering political style is out of date" ${ }^{16}$.

13 From exercising political, economic and legal restraint on the media so that they might serve a distinct ideological and developmental agenda, the KMT had moved to a position where the party recognised that its ambition for a democratic society was impossible without a free and independent media. This was the first tentative step in 
the separation of the media and politics in Taiwan, an aspiration for which President Chen Shui-bian assumed full responsibility after his inauguration in 2000.

Under Chen Shui-bian

Chen's election campaign identified political influence in the media as an urgent problem that required resolution. Given that his party, the Democratic Progressive Party (DPP) had suffered from the KMT's monopoly on information and media ${ }^{17}$. Chen's interest in this matter was not surprising. To realise his ambition of separating the media and politics (processes and institutions), Chen understood that he would first have to deal with the issue of media ownership.

The outlook was promising. First, Chen's administration announced that it would relinquish its shares in the media. Then, the government could make a start in limiting partisan and state influence in the media. While the former objective was easy to achieve, the latter aim was less successful for three reasons: first, while noble in vision, it was difficult to accomplish, and the government has never formulated a coherent plan to suggest a solution. Second, the political environment is not particularly conducive to such reforms. Although Chen won the presidency in 2000, a "blue" majority in the Legislative Yuan has routinely hampered the administration's reforming efforts of a number of serious issues. Third, the political interests in the media were so powerful and so embedded that it would be tricky to untangle the complex corporate patron-client network that structured the media industry.

In fact, members of the DPP enjoyed privileged positions within the media industries during the process of liberalisation and were themselves reluctant to concede to change. The most prominent case was that of Cai Tong-rong (Trong Chai), a DPP legislator and member of the party's Central Standing Committee. While serving as an elected representative, he also worked as chair of Formosa Television (FTV), a DPPsupporting national television station that he helped to establish in 1997 to break the KMT's broadcasting monopoly ${ }^{18}$. This was a significant test case; if the DPP was seen to be so serious in separating media from politics that it was prepared to lose such highlevel control of the only television station that openly supported the party, the sincerity of the administration could not be questioned. Under pressure from the government and the media, Cai announced his resignation in September 2003.

The then Director-General of the GIO, Chung Chin, was tasked with finding a solution. "Our basic aim, she told the Education and Culture Committee of the Legislative Yuan, is to filter out improper influences, both political and commercial, that may stand in the way of the neutrality of news gathering and presenting" ${ }^{19}$. The proposed means of accomplishing this aim were unimaginative and had little effect. The committee discussed, and then shelved its proposal to prevent government, state or political parties from owning majority shares in media enterprises. The suggested reason for the setback was the members' reluctance to take potentially controversial steps that might undermine the freedom of speech Taiwan had only just acquired. 


\section{Ownership of TTV, CTV, CTS and FTV}

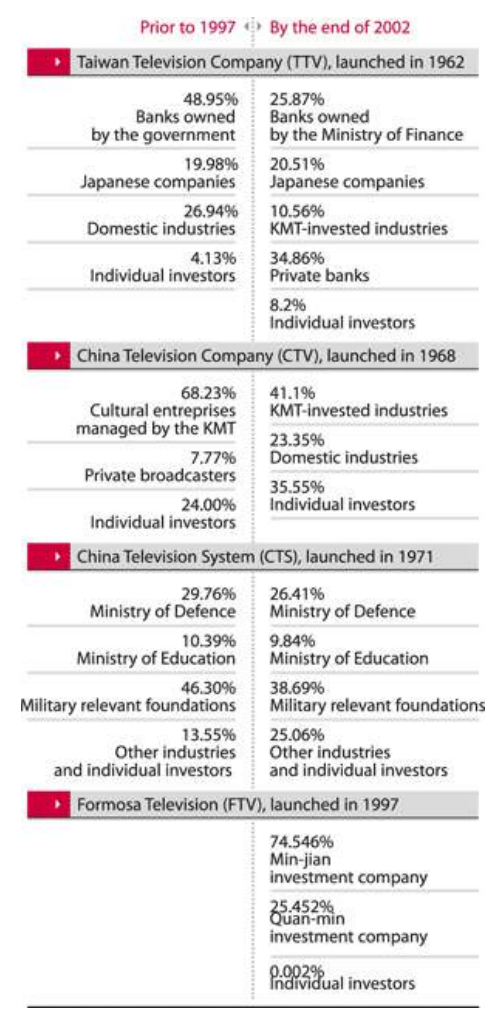

Sources: Wang Zhen-huan, "Guangbo dianshi meiti de kongzhi quan" (Control of the Broadcasting and TV Media), in Zheng Rui-cheng et al. (eds.), Jiegou guangdian meiti: jianli guangdian xin zhixu (Deconstructing the Broadcasting Media: Establishing a New Order for the Broadcasting Media), Taipei, Cheng Society, 1993, pp. 77-128; Ming-Yeh T. Rawnsley, Public Service Television in Taiwan, unpublished PhD thesis, University of Leeds, 1998; Chen Bing-hong, Jiegou meiti (Deconstructing the Media), Taipei, Yeh-yeh Book Gallery, 2003,

pp. 289-290

However, the Legislative Yuan did finally succumb to executive pressure and passed the reforms. In February 2003, the KMT announced that it would comply with the new law and sell its stockholdings ${ }^{20}$. Such remedies to a seemingly intractable problem were only possible with the political will of all political parties, and especially the opposition KMT that had most to lose from these reforms. For their part, TTV and CTS face two options for future reform. Either they can become part of a new public television group, or they can follow CTV's example and become fully privatised organisations. At the time of writing (July 2004) 25\% of Taiwan Television Company belongs to banks owned by the Ministry of Finance, and the Ministries of Defence and Education still control the Chinese Television System (see Table 1). The difficulties in overcoming traditional ownership patterns are most telling, and it is unfortunate that partisan and government influence is still pervasive.

In the same way that ownership of television stations lends credibility to accusations of political bias, so the press are routinely criticised for being partial to one particular party. The United Daily News and the China Times, the two broadsheets with the highest circulation in Taiwan, have been rounded on as a mouthpiece of the blue alliance, especially during the 2004 presidential election. Critics have discovered an apparent absence of professionalism among journalists and editors working for these 
newspapers, suggesting that they do not follow the news agenda, but choose instead what to cover and how from a blue political perspective ${ }^{21}$.

This is a serious, but unfair accusation, as newspapers throughout the democratic world tend towards bias in favour of one political party or platform. In a commentary in the English language Taipei Times, Lee Ming-tsung alluded to the "emotional and slightly emotional language" that the China Times and United Daily News used to describe protestors following the 2004 presidential election, concluding that "it is probably better to call that material 'propaganda' rather than 'reports' or 'commentaries"'22. Yet, no one familiar with the tabloid press in Britain-especially those that position themselves on the right wing of the political spectrum-will be surprised that newspapers in democratic societies can act in this way. In fact, Taipei Times is a sister newspaper of Taiwan's Chinese-language broadsheet with the third highest circulation, Ziyou shibao (Liberty Times). Both the Liberty Times and the Taipei Times follow their own political agendas in favour of the "green" (i.e. pro-DPP) alliance. In other words, KMToriented newspapers may dominate the market, but alternative newspapers promoting alternative political platforms are available. Again, this is not unusual; in Britain, the newspaper market is dominated by titles that are supportive of the political right. Yet, the left-leaning Guardian newspaper is sold alongside the more Conservative Daily Telegraph. The bias is overt, and the choice of opinion available to the average newspaper reader is considered a blessing ${ }^{23}$.

Neither should we overlook the influence of cable television in Taiwan. In addition to the four major national television stations, there are hundreds of cable channels competing for audience attention. Since legalisation in 1993, cable television has become an increasingly powerful source of information, especially during elections. According to the Advertising Yearbook of Taiwan, for the elections of the Legislative Yuan in 2001, the political parties spent about NT\$2 billion in advertisement on non-cable television and NT $\$ 5.5$ billion in cable television ${ }^{24}$. An advertisement of just ten seconds on TTV, CTV and CTS would cost NT $\$ 33,000$ and on TVBS NT $\$ 30,000^{25}$. There are currently six major cable system operators (see Table 2), and while some are inclined towards the blue camp, most are far more concerned with making profits and therefore do not operate according to any specific political agenda,.

Another method that Taiwan's government has tried to facilitate the separation of politics and media is to regulate the tendency for politicians to control their own television or radio stations, or become media celebrities by hosting their own programmes. As of March 2003, 15 elected politicians hosted or produced television or radio talk shows. The most prolific was the independent legislator, Chen Wen-chien (Sisy Chen). Until April 2003, Chen hosted Sisy's News on Star TV, in addition to a daily radio talk show, UFO Dinner, on UFO Radio. In March 2003, her contract with Star TV was not renewed because, she believes, the station was pressured to drop her by the ruling DPP. Star Group Taiwan Ltd. denied political pressure, claiming that there are already too many political talk shows on air. Star TV also broadcasts former politician Jaw Shaw-kong's News Hijacker, while legislator May Chin hosts Lighting the Lamp on CTS and Shen Chih-hwei (a legislator with the PFP) is responsible for a daily talk show on Taichung radio. Many politicians have profited-politically and commercially-from the proliferation of cable television and radio channels that are relatively simple to launch and have small set-up costs. These shows are important as they give the politicians a medium through which they can address their own local constituencies 
free from mediation by journalists. Most importantly, however, is that the celebrity politicians listed here are from the blue alliance, adding to the suspicion of widespread media bias. Some may suggest that the DPP has a right to be concerned that it is playing on an uneven field; others would say that the DPP is merely trying to mute those voices that stand in opposition to their own, and thus restrict Taiwan's much cherished freedom of speech.

To circumvent some of the problems associated with this tendency, President Chen issued an ultimatum to Taiwan's politicians towards the end of his first term in office: all elected politicians and officials should relinquish their media interests by September 5th 2003. This affected 58 persons who were now required to choose between their dual roles in politics and the media. The law does not affect the politician television and radio hosts who do not have commercial interests in particular media enterprises, since its intention is to prohibit civil servants and political party members from owning, funding or acting as founder, director or manager of stations and newspapers. However, this caveat did not satisfy everybody. Some legislators argued that the government should prevent elected politicians from producing or hosting political and/or news programmes on television and radio. For example, the DPP legislator, Julian Kuo, remarked, "Politicians hosting or producing broadcast shows is just like athletes serving as referees in a single game" ${ }^{26}$.

However, critics have accused the DPP of hypocrisy in its ambition to separate completely the media and politics, and have indicted the administration for using government communication resources for its own partisan purposes. When in opposition, the DPP regularly censured the KMT's media monopoly because it allowed the government to use public channels of communication for party propaganda. This suspicion resurfaced in March 2003, when the GIO announced it planned to integrate various government agencies' resources to buy airtime and advertisement space in the media to promote government policies. The funding would provide the resources for a NT\$200 million promotion between April 1st and June 1st 2003, and NT\$900 million more from July 2003 to March 2004. This means that instead of entitling all government departments to purchase airtime and advertising space to promote their individual policies, the GIO combines all departmental promotional budgets to facilitate a single annual bulk purchase of media space. In March 2003, the GIO revealed that it has spent more than NT $\$ 30$ million in 2002 to buy television airtime to promote government policies.

The opposition viewed such initiatives as a way to kick-start Chen Shui-bian's election campaign at the taxpayer's expense, despite the GIO being the government (and not the DPP) Information Office. The opposition claimed that such moves are a clear danger to press freedom and contradict the DPP's apparent determination to end political involvement in the media. However, by merely criticising the plans the blue alliance failed to see the wider picture. The problem is not one of allowing the government to use the GIO in this way (after all, it is the responsibility of the government to publicise policies and thus be accountable to public opinion), but one of ensuring that all political parties compete with each other on a level playing field. The key question is how the political system can ensure that the GIO remains the spokesperson of the government and not whichever party happens to be in power. The blue opposition has clearly failed to differentiate between party and government propaganda, which is not surprising since the distinction was non-existent before 1987 . 
b much media regulation is required in a liberal-democratic free market system? This is becoming an urgent matter given the rapid and disturbing development of more inquisitive media that are quite prepared to engage in less reputable and more sensationalist styles of reporting. So-called "yellow" or tabloid journalism thrives in Taiwan on a scale never before imagined. The most recent entrant to Taiwan's newspaper market is Pingguo ribao (Apple Daily), run by Hong Kong entrepreneur Jimmy Lai. Apple Daily, a tabloid newspaper with a reputation for celebrity gossip, scandal, and crime scene photographs, was first established in Hong Kong and hit Taiwan's newsstands on May 2nd 2003 with a claimed circulation of 750,00027. It follows the success of Jimmy Lai's first Taiwan venture, Yizhoukan (Next Magazine), which is now the island's biggest selling weekly. For the Taiwanese, free speech is synonymous with democracy, and here we identify a fundamental problem that is a serious barrier to further reforms designed to encourage quality. The president of one prominent NGO, Taiwan Media Watch, outlined the dilemma: When does freedom of speech end and moral responsibility begin? ${ }^{28}$ The apparent lack of media sensitivity in reporting disasters, crime and personal tragedies suggests that they are incapable of exercising the kind of professional self-discipline and self-regulation called for. "Any government intervention in the operations of the media is unacceptable because freedom of the press is pivotal in a civilised society. But as the tendency towards indecency looms large in our local TV programming, to expect self-discipline on the part of the media is a difficult option. So the only feasible solution is to allow the public to use its voice to tell the media what they consider to be quality TV programmes" 29.

Under Chen Shui-bian, the GIO has discussed ways of monitoring media output to combat the growth in tabloid-style journalism, but has also tried to design a regulatory framework that would allow journalists to carry out their work free from the fear of government interference and retribution. Again, however, progress has been slow. In June 2002, the GIO reviewed a draft Mass Communications Law designed to "better regulate Taiwan's media" ${ }^{30}$. The mooted Law would "ban invasions of privacy by the media and prevent the media from violating an individual's 'autonomy'. It would also more clearly delineate the ratings system for media content and upgrade the level of media regulations from that of executive orders to full legal standing". In other words, the system that the GIO designed actually reinforces control over the media, rather than protecting the media from government interference. Huang Hui-chen, the DirectorGeneral of the GIO after 2003, conceding “Taiwan's freedom of speech is among one of the most liberal in the world" [sic], did warn that "such freedom should not be abused. The media's responsibility should be to imbue audiences with positive social values ... The GIO has been aggressively imposing fines and rating television programmes, and we take our responsibilities very seriously" ${ }^{31}$.

One of the most controversial decisions taken by the GIO was its award of NT\$950,000 to the Foundation for the Prevention of Public Damage by the Media to fund the regular evaluation of the six mainstream Chinese-language newspapers. This would measure "justice, objectivity, appropriateness and accuracy", with the results released to the 
public every two months. Critics of this proposal not only question the methodologyhow can one measure justice and appropriateness?-but also deem the exercise a step backwards that will only damage press freedom. The proposals extend to the broadcast media and the signs are not particularly encouraging: "Concerned that locally produced TV programmes are becoming increasingly sensationalistic or inaccurate, the Radio and Television Affairs Department of the GIO has decided to begin monitoring and evaluating local programmes. (...) Because many TV shows have damaged some people's privacy and the sensationalism of some programmes has made audiences uncomfortable, we have decided to take action and manage TV shows", said Hong Chongjan, the new director of the department ${ }^{32}$. Such management undermines Chen Shuibian's commitment that "the government would not suppress the freedom of the press or people's freedom of speech under the pretext of national security considerations", and he urged the media to develop processes of self-regulation.

The government has continued to accrue powers in order to provide the conditions for "quality". In October 2003, the preparatory office of the new National Communications Commission (NCC, guojia chuanbo weiyuanhui) opened. This independent organisation responsible to the Executive Yuan, will oversee and regulate the telecommunications, media and information technology sectors. Its creation reflects the convergence of information technology. Thus mobile telephones, the internet and cable technology have blurred the differentiation between broadcasting and communication. More ominously, the NCC is responsible for censoring online data, television and radio programmes and other information broadcast through channels of mass communications. The members of the commission are political appointees, chosen by the premier for five-year terms, and would replace the GIO.

31 Are these examples of Taiwan taking one-step forwards, two steps back? Can the government really imbue quality within the media and inspire journalists to higher standards of professionalism by legislating for it? The government does have to create the framework for satisfactory self-regulation that will set acceptable standards for quality (for example conceding more powers to media-interested activists and groups within civil society) rather than trying to interfere directly with the producers and their products.

One of the most urgent challenges that Taiwan's media face in a democratic environment is the absence of specific laws that define and regulate classified information. The existing arbitrary definition of what is and is not allowed continues to confer upon the government and the GIO almost the same leverage over the media as its KMT predecessors. For example, Article 21 of the Broadcasting and Television Law forbids television programmes from spreading rumours or presenting material in a way that would disrupt law and order, but fails to provide any specific details or speculate on circumstances when the government might invoke this law. It is worrying that neither the media nor the government are clear where the boundaries are, what is permissible, and who is responsible if things go wrong. The Chen Shui-bian administration has so far failed to demarcate these boundaries, which means that journalists are still vulnerable to abuse and intimidation. They are often under surveillance, their offices may be searched, and sometimes their telephones (and those of family and friends) are bugged. searched the offices and homes of journalists working for the Zhongshi wanbao (China 
Times Express). They were searching for information about corruption within the National Security Bureau that officials had leaked to the media. Journalists complained that they, and their friends and families, were under close surveillance, and their telephone conversations monitored. The prosecutors justified their action with reference to "national security". They claimed the leaked information could have included "highly sensitive state secrets" that threatened the lives of bureau members.

More often, however, the intimidation is non-political and originates with the criminal underworld. Official prosecutors have searched the offices of Jimmy Lai's Taiwan enterprise, Next Magazine, and hired thugs have vandalised them following the magazine's exposure of criminal activity. One of the more subtle, but increasingly popular, forms of intimidation is the threat of libel suits. In fact, Antonio Chiang, briefly the publisher of the Taiwan ribao (Taiwan Daily) in 1996, once said that his main job was "to go to court", especially when his newspaper was sued six times in a three month period. In other words, libel laws remain a serious risk to Taiwan's media freedom, but they are necessary given the growth of sensational reporting that violates the privacy of people in the public eye. Again, progress rests on finding a balance, and ensuring that the libel laws are so tight that both sides-media and public-know precisely what laws are being broken, the punishments they can expect, and when recourse to the courts is acceptable.

Liberal commentators have identified as the solution to problems within the media, especially ownership patterns and obvious bias, market mechanisms that concede greater power to the consumer. Reviewing the government's plans to reform the media by imposing new regulations, one anonymous member of President Chen's Cabinet said, "The less government interference, the better. If the public dislikes a certain TV channel or radio station which they think is manipulated by a certain party or individual they detest, they simply refuse to watch it or listen to it. It's that darn simple." The short life of the Shoudu zaobao (Capital Morning Post), established in May 1989 and financed by a prominent DPP politician, Kang Ning-hsiang, clearly demonstrates the power of market forces. The newspaper closed down in August 1990 not because it voiced unpalatable or unpopular political opinions, but because it could not capture an adequate share of the market. In 2000, the GIO informed the Taiwan xinwen bao (Taiwan Daily News), a newspaper owned by the Taiwan Provincial Government and based in Kaohsiung, that it might have to close down if it did not make a profit. To turn its fortune around, the publication had to downsize into a local newspaper and make two hundred of its staff redundant. Even state-controlled media are not immune to the hidden hand of the market ${ }^{33}$.

However, the market does not guarantee quality. As competition intensifies, the media are less willing to invest in innovative programming and instead battle to capture the same middle-ground audiences with the same formats. This is particularly serious in television, where the national stations now compete with the cable channels that are gaining popularity ${ }^{34}$.

Moreover, the idea that competition provides opportunities for consumer-power is a little disingenuous. While the government has made important strides in ending political influence in the media, close examination of the cable television industry reveals a concentration of power in the hands of a few very powerful consortiums. The Cable Television Law, passed by the Legislative Yuan in 1993, stipulated that to prevent the creation of a monopoly, two or more operators should serve each geographic area 
of Taiwan. However, fierce competition ensued, whereby cable operators blocked channels belonging to their competitors regardless of their popularity with audiences. In the meantime, it is not unusual for bigger operators to squeeze their smaller competitors out of the market. In contrast to the aims of the Cable Television Law, each area is dominated by one cable operator, with two or more able to exist in only a few areas (Table 2).

2. An overview of the cable market to December 2002

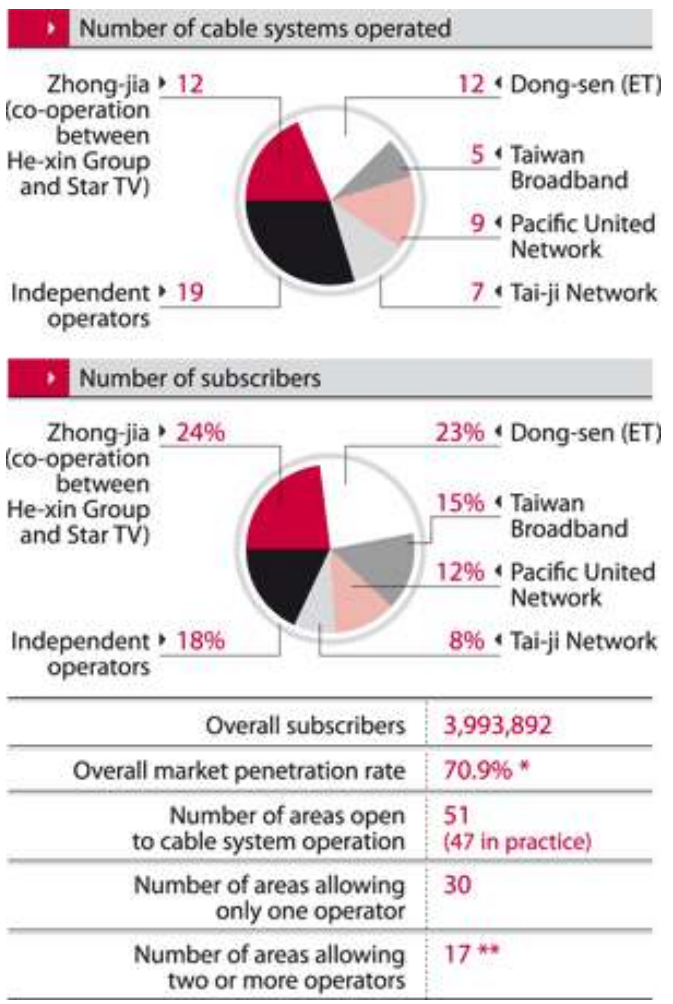

Source: Chen Bing-hong, Jiegou meiti, op. cit., pp. 291-292.=

NB : * This figure is based on the calculation that 5.55 million households island-wide subscribed to cable television.

** Some of the operators use different company names to apply for licences. Therefore, it appears

that there are two or more competitors. However, in reality, they belong to the same consortium.

Since winning control of the presidency in 2000, Chen Shui-bian's administration has proposed numerous technical amendments to the Cable Television Law to reduce the possibility of broadcasting monopolies by powerful consortiums. However, the impact has been minimal for the same reasons that reform has been difficult in other areas of the media, namely a blue-dominated Legislative Yuan battling with a DPP executive, and the political and commercial interests of legislators in blocking reform.

Taiwan's media have experienced a dramatic and rapid transformation since 1987. From having politically defined responsibilities that were designed to further the KMT government's agenda, the media are now in a stronger position than ever to interrogate the decisions, actions and behaviour of politicians. The transparency and accountability that are characteristic of Taiwan's media today are important benchmarks of the level of democracy there. While we must acknowledge the role of the KMT in building the foundations for these circumstances, we must nevertheless recognise the progress under the Chen Shui-bian administration. Problems persist: the 
issue of ownership has yet to be resolved to everyone's satisfaction, while political bias within the predominantly blue media continues to be particularly worrisome, especially during elections. Moreover, the quality of output, and particularly the quality of journalism, is cause for concern. A noticeable decline in deference to authority, prompted by the gaining of freedom of speech, media pluralism and competition, and the rising power of market over state forces, have encouraged the government to think about the problems posed by a completely free and independent media in a liberal-democratic society. Moreover, what is the relationship between the legal process and the media? Here, Taiwan faces a dilemma: can the government legislate for quality, and thus risk being criticised for impeding the freedoms the media fought long and hard to attain? Or can it depend on the power of market competition and the consumer-his right to choose not to buy a particular newspaper or turn the television over to a different channel-to regulate the media?

The SARS epidemic of 2003 was a particularly testing time for Taiwan's news media, and the debate over where to draw the line between the public's right to know and journalistic sensationalism continued long after the World Health Organisation removed Taiwan from its list of SARS-affected areas. One poll discovered that $65 \%$ of 1,093 respondents thought SARS-related news reports were "overly sensational. Another $30 \%$ described them as unnecessarily and intolerably repetitive. It seems that accurate information was difficult to come by, and that the competitive 24 hours news environment made speed of reporting more important ${ }^{35}$. Industry insiders claim that practices associated with professional journalism, such as double-checking the facts and the reliability of sources, were sacrificed. All media are now desperately trying to learn from their experience of the SARS crisis. However, such problems are not culturally specific; British and American media faced similar criticisms of their coverage of the 2003 war against Iraq. Few reporters on the front line have military expertise, while the British government and the $\mathrm{BBC}$ are embroiled in a volatile dispute about the reliability of sources. Perhaps Taiwan's experience during the SARS outbreak demonstrates that, after all, its media are simply responding to the challenges of democratic society. It is a steep learning curve for all concerned.

\section{NOTES}

1. Emphasis added.

2. Freedom House, for example, uses the media as a quantitative and qualitative indicator in measuring democracy around the world. See "Freedom in the World" at http://216.119.117.183/research/freeworld/2001/table1.htm

3. See Gary D. Rawnsley and Ming-Yeh T. Rawnsley, Critical Security, Democratisation and Television in Taiwan, London, Ashgate, 2000.

4. The "blue" alliance refers to the Kuomintang, the People's First Party (Qinmindang) and the remnants of the New Party (Xindang).

5. See Frank Muyard, “Taiwan, the birth of a nation?”, China Perspectives, No. 53, MayJune 2004, pp. 33-48. 
6. On consolidation see G. O'Donnell, P.C. Schmitter, and L. Whitehead (eds.), Transitions from Authoritarian Rule, 4 vols., Baltimore, Johns Hopkins University Press, 1986; Samuel Huntington, The Third Wave: Democratisation in the Late Twentieth Century, Norman, University of Oklahoma Press, 1991; L. Diamond, M. F. Plattner, Y. H. Chu, and H. M. Tien (eds), Consolidating the Third Wave Democracies: Regional Challenges, Baltimore, Johns Hopkins University Press, 1997. Taiwan has yet to take Huntington's "two-turnover test", whereby consolidation is characterised by the incumbent party (the DPP) suffering electoral defeat. See Huntington, The Third Wave, pp. 266-267. 7. See Xinwen yewu shouce (Manual for the Information Professions), Taichung, Information Department of Taiwan Provincial Government, 1983, p. 17.

8. Passed in April 1952, amended in 1958 and 1973, finally repealed on January 25th 1999.

9. The Law on Publications and other texts imposed restrictions on: (i) the registration of new papers; (ii) the number of pages that newspapers could publish; and (iii) where the newspaper could be printed and distributed. These measures affected a comprehensive press ban policy of 1951, which prevented the further issue of licences and thus froze until 1987 the number of titles permitted to be printed at 31 .

10. Patricia Batto, “Democracy's Impact on Dailies", China Perspectives, No. 51 JanuaryFebruary 2004, p. 65.

11. Bruce J. Jacobs, “Taiwan's Press: Political Communications Link and Research Resource”, China Quarterly, Vol. 68, No. 4, 1976, pp. 778-788. However, Taiwan Times became more politically conservative after 1982 following its purchase by the Wang family in Kaohsiung.

12. On the importance of the underground illegal media to Taiwan's political development, see G. D. Rawnsley, “The Media and Popular Protest in Taiwan”, Historical Journal of Film, Radio and Television, Vol. 20, No. 4, 2000, pp. 565-580.

13. With a cable penetration rate of $82 \%$, Taiwan is the most heavily saturated pay-TV market in the world, surpassing even the United States and Japan. Alkman Granitsas, "Digital to the Rescue", Far Eastern Economic Review, October 17th 2002, pp. 46-48. Cable operators in Taiwan usually produce at least four sets of figures regarding the number of their subscribers: to the channel operators, they provide a low figure in order to pay the least money possible; to the GIO, they provide a "moderate" figure in order to ensure their market penetration does not exceed the legal limits; to the advertisers, they provide a high figure to raise as much advertising revenue as possible; the figures they tell themselves are secret. This explains why the penetration rate presented here is different from the figure provided in Table 2 (i.e. discrepancies in the sources used). 14. A branch of the Executive Yuan, the Government Information Office (GIO) "is responsible for clarifying national policy, publicizing government ordinances and administrative achievements, releasing important information at home and abroad, effectively employing the mass media, actively developing overseas information and cultural projects, and strengthening cultural communication to mainland china. The office thus offers a wide variety of information services to the media and individuals at home and abroad". Republic of China Yearbook, 1996, Taipei, GIO, 1996.

15. Quoted in Batto, “Democracy's Impact on Dailies”, op. cit., p. 71.

16. Ibid.

17. Before the DPP was formed and legalised, the tangwai (i.e. "party outsiders") had published a number of underground or dissident journals that provided a means of 
organisation, recruitment and mobilisation for the opposition movement. See Rawnsley, "The Media and Popular Protest", op. cit.

18. See Ming-Yeh T. Rawnsley, "Communications of identity in Taiwan: from the February 28th incident to the Formosa Television Corporation", in Gary D. Rawnsley \& Ming-Yeh T. Rawnsley (eds.), Political Communications in Greater China, London, RoutledgeCurzon, 2003, pp. 147-166.

19. Taipei Times online, June 2nd 2000.

20. $41.1 \%$ in China Television Company (CTV), $97 \%$ in the Broadcasting Corporation of China (BCC), and 7 million shares in Taiwan Television Company (TTV).

21. See Lee Ming-tsung, "Media outlets more blue than blue", Taipei Times, April 6th 2004, p. 8.

22. Ibid.

23. Similar views are also expressed in Taipei Times online, Editorial, "In response to our critics", January $12^{\text {th }} 2004$.

24. Zhonghua minguo guanggao nianjian (Advertising Yearbook of Taiwan, the ROC, 2001-2002), p. 97.

25. Ibid, pp. 328-332.

26. Taipei Times online, March 3rd 2003.

27. Newspapers in Taiwan sometimes provide contradicting figures. According to alternative data, Apple Daily claimed a circulation of only 400,000 at the end of 2003. See Batto, "Democracy's Impact on Dailies", op. cit., p.76.

28. Taipei Times online, June 5th 2000.

29. Ibid.

30. Emphasis added.

31. "New group takes aim at 'vulgar' TV", Taipei Times online, October 12th 2003.

32. Emphasis added.

33. Taiwan Daily News is not the only state-controlled media threatened by the market. In fact, all former so called "public" media that were owned or subsidised by the state, government or the military have had huge financial difficulties since 1987, for example, the two faithful KMT titles, Zhonghua ribao (China Daily News) and Zhongyang ribao (Central Daily News).

34. Since the reception and transmission of cable television was legalised in 1993, the audience for the national television stations has declined at a dramatic rate. In 1994, $73 \%$ of the viewing public preferred to watch national television, TTV, CTV and CTS; in 2001 , these stations could capture only $42 \%$ of the audience. See Chen Bing-hong, Jiegou meiti (Deconstructing the Media), Taipei, Yeh-yeh Book Gallery, 2003, pp. 78-80.

35. There are currently more than ten domestically-produced 24-hour news channels in Taiwan for a population of 23 million, while there are only two such channels in the US (CNN and Fox News) and three in the UK (BBC News 24, the ITV News Channel and Sky News). 


\section{ABSTRACTS}

Media reform is a valuable indicator of democratisation. It provides an abundance of information about the levels of freedom, tolerance, social justice and pluralism within a political system. This article reviews the changes in the Taiwanese media that have occurred since the lifting of martial law in 1987 and considers how the media are faring at the beginning of Chen Shui-bian's second term. Taiwan's media are still at an early stage of democratisation but it cannot be denied that progress has been made and that Taiwan's media are looking increasingly like those operating in systems at comparatively similar stages of democratic consolidation. 